The Editors of the Proceedings of The Nutrition Society accept no responsibility for the abstracts of papers read at the Society's meetings for original communications. These are published as received from the authors.

\title{
ABSTRACTS OF COMMUNICATIONS
}

The One Hundred and Sixty-second Meeting of The Nutrition Society was held at the Edinburgh School of Agriculture, King's Buildings, West Mains Road, Edinburgh, on Saturday, 22 February 1964, at I pm, when the following papers were read:

Measurement of total body fat in man with ${ }^{85}$ krypton. By F. E. Hytten, Obstetric Medicine Research Unit (Medical Research Council), Maternity Hospital, Aberdeen

Methods available for estimation of body fat in the living subject are unsatisfactory. The standard method relies on a measurement of body density, and it is assumed that all adult normal humans are identical in their ratios of water, protein, and mineral, and that they differ only in possessing varying proportions of pure fat appended to the basic lean structure' (Siri, 1956). This assumption, valid for small mammals, has been questioned for man and certainly does not hold in states of abnormal hydration including pregnancy.

A more direct approach is to introduce a tracer substance to the body which is soluble in body fat. Two substances with suitable characteristics are cyclopropane and krypton. The use of ${ }^{85}$ krypton was first suggested by Davidsson, MacIntyre, Rapoport \& Bradley (1956) and both cyclopropane and stable krypton were used in a few subjects by Lesser \& Zak (1963). Davidsson et al. present no data. The eight subjects of Lesser \& Zak rebreathed krypton from a standard spirometer and equilibration had not occurred after $7 \mathrm{~h}$. The authors assumed an exponential disappearance curve and calculated the equilibration level. Some of their estimates of total body fat appear to be grossly excessive.

Preliminary trials in this laboratory showed that krypton will never equilibrate in a system where it can escape through the water seal of the spirometer bell. Using a closed circuit with neoprene bellows equilibration takes about $1 \frac{1}{2} \mathrm{~h}$ for an average subject, longer for the more obese. With a spirometer volume of about 71 ., $20 \mu \mathrm{c}$ of ${ }^{85} \mathrm{Kr}$ gives a satisfactory counting rate, and after equilibration, the average person will have taken in about $8 \mu \mathrm{c}$ giving a total radiation dose of about 0.3 mrads. The final concentration of krypton, after equilibration, gives the krypton space of the body equivalent to: lung + mask volume (helium space) + water volume (deuterium space) $\times$ solubility in water + fat volume $\times$ solubility in fat. Four male subjects

Table. Body composition of four adult males

$\begin{array}{cccccc}\text { Subject } & \begin{array}{c}\text { Height } \\ (\mathrm{cm})\end{array} & \begin{array}{c}\text { Weight } \\ (\mathrm{kg})\end{array} & \begin{array}{c}\text { Body fat } \\ (\mathrm{kg})\end{array} & \begin{array}{c}\text { Hody water } \\ (\mathrm{kg})\end{array} & \begin{array}{c}\text { Hydion of } \\ \text { lean body mass } \\ (\%)\end{array} \\ \text { Y } & 169 & 56 \cdot 5 & 2 \cdot 1 & 35 \cdot 5 & 65 \cdot 3 \\ \text { H } & 182 & 79 \cdot 1 & 15 \cdot 6 & 44 \cdot 6 & 70 \cdot 3 \\ \text { D } & 184 & 91 \cdot 1 & 11 \cdot 7 & 57 \cdot 7 & 72 \cdot 7 \\ \text { M } & 177 & 123 \cdot 5 & \mathbf{2 4 \cdot 2} & 62 \cdot 2 & 62 \cdot 6\end{array}$


have been measured and details are shown in the table. Although further technical development is required, the method appears to be capable of giving realistic results.

\section{REFERENCES}

Davidsson, D., MacIntyre, I., Rapoport, A. \& Bradley, J. E. S. (1956). Biochem. F. 62, 34 P.

Lesser, G. T. \& Zak, G. ( 1 963). Ann. N.Y. Acad. Sci. I10, 40.

Siri, W. E. (1956). Body composition from Fluid Spaces and Density: Analysis of Methods. Donner Laboratory, University California, Publ. UCRL-3349.

Effects of progesterone on energy balance in rats. By G. R. HERVEY, Physiology Department, University of Aberdeen

Following Thomson \& Hytten's (196r) demonstration that normal human pregnancy entails an increase of maternal weight and fat stores, Galetti \& Klopper (1964) have reported that progesterone given to young adult female rats caused increased weight gain, due largely to fat. The present communication reports an attempt to investigate the mechanism by which progesterone disturbs energy balance.

Progesterone, $5 \mathrm{mg}$ /day given subcutaneously in an oily solvent, has been given for 12 -day periods to rats initially 3 months old, living in drum-type activity cages (Richter \& Wang, 1926). Progesterone administration led to a marked increase in the rate of weight gain in female rats. When allowance was made for changing body size due to normal growth, there appeared to be no change in the amount of food eaten. The distance the rats ran daily in the drum decreased markedly. Cessation of progesterone injections was followed by a rapid fall of body-weight, roughly to the original growth curve, and by a fall in food intake, which lasted for about a week (see table, which gives mean values in successive periods for two female rats aged $2 \frac{1}{2}$ months at start). When running was prevented by closing off access to the drums, there was no change in the rate of weight gain, and food intake was reduced. Administration of progesterone still led to increased weight gain; food intake per unit of body-weight again did not appear to change. Water intake ran approximately parallel to food intake throughout. Progesterone did not cause changes in weight gain, food intake or running in male rats.

It seems clear that, although progesterone causes reduction in voluntary exertion, this effect is not the direct or the only cause of the positive calorie balance. There is a change in the regulation of food intake, for intake does not decrease, in a situation in which it would do so in an untreated animal; and it does fall when progesterone has been withdrawn. Since progesterone appears to affect activity, food intake, and possibly some other aspect of energy expenditure in an integrated way, and also in the light of the sex difference, it is tentatively suggested that the site of action may be on regulating centres in the hypothalamus.

This investigation was supported by United States Public Health Service grant no. $\mathrm{AMO}_{7627-01 \text {. }}$ 


\begin{tabular}{|c|c|c|c|c|c|}
\hline Vol. 23 & $g$ of & Februar & 1964 & & xxiii \\
\hline $\begin{array}{l}\text { Duration (days) } \\
\text { Treatment }\end{array}$ & 12 & $\begin{array}{c}12 \\
\text { Olive oil }\end{array}$ & $\begin{array}{c}12 \\
\text { Progesterone } \\
5 \mathrm{mg} / \text { day }\end{array}$ & $\frac{8}{-}$ & 12 \\
\hline Weight gain (g/day) & 1.0 & I.O & $2 \cdot 5$ & $-1 \cdot 6$ & 0.5 \\
\hline $\begin{array}{l}\text { Daily food intake: } \mathrm{g} \\
\qquad \mathrm{g} / 200 \mathrm{~g} \text { body-weight }\end{array}$ & - & $\begin{array}{l}22 \cdot 9 \\
24 \cdot 6\end{array}$ & $\begin{array}{l}24 \cdot 6 \\
24 \cdot 7\end{array}$ & $\begin{array}{l}23 \cdot 6 \\
22 \cdot 3\end{array}$ & $\begin{array}{l}26 \cdot 0 \\
24 \cdot 7\end{array}$ \\
\hline $\begin{array}{c}\text { Distance run }(\mathrm{km} / \text { day) } \\
\text { Non-oestrous days } \\
\text { Oestrous days }\end{array}$ & $\begin{array}{l}4.0 \\
7.8\end{array}$ & $\begin{array}{r}57 \\
13.5\end{array}$ & $\begin{array}{l}3 \cdot 2 \\
2 \cdot 5\end{array}$ & $\begin{array}{r}7.5 \\
15.1\end{array}$ & $\begin{array}{r}7 \cdot 7 \\
18 \cdot 3\end{array}$ \\
\hline
\end{tabular}

REFERENCES

Galetti, F. \& Klopper, A. (1964). Acta endocr. (Copenh.) (In the Press.)

Richter, C. P. \& Wang, G. H. (1926). F. Lab. clin. Med. 12, 289.

Thomson, A. M. \& Hytten, F. E. (196i). Proc. Nutr. Soc. 20, 76.

A review of obese patients on subcaloric diets. By KATHLEEN Rose and D. A. Seaton, Dietetic Department and University Department of Therapeutics, Royal Infirmary, Edinburgh

The case records of 1000 consecutive patients considered to be overweight and given subcaloric diets during a period of ${ }_{5}$ months at the Dietetic Department and Diabetic Clinic of the Royal Infirmary of Edinburgh are reviewed.

There were 707 females and 293 males. Five hundred and fifty-five patients were referred from other out-patient departments, 299 were seen on discharge from the wards of the hospital and the remaining 146 came directly from their own doctors. Diabetes mellitus was detected in 98 patients and a further 344 were under treatment for other disorders. Many occupations were represented, the largest single group being housewives who numbered 454 ; those in occupations of moderate physical activity numbered 302 , those in sedentary occupations 157 and the remainder formed small miscellaneous groups. There was considerable variation in the degree of obesity with I 15 patients more than $50 \%$ in excess of their standard weight for height and age, 506 of $20-49 \%$ overweight, 350 less than $20 \%$ overweight and 29 patients below their standard weight. Two hundred and six patients were below 40 years of age, 5 I 9 between 40 and 59 years and 275 of 60 or more years but the proportion of patients under 40 years increased with the greater degrees of obesity and that over 60 years with the lesser degrees of obesity.

The patients were all instructed in the principles of subcaloric diets ranging from 800 to $1800 \mathrm{kcal}$ adapted to suit their individual requirements and asked to return for review at monthly intervals. Two hundred and thirty-nine $(24 \%)$ failed to return and in a I-year follow-up period $33 \circ(33 \%)$ attended for 6 months or more. The most reliable attenders were the very obese, elderly patients and also those with diabetes of whom only $6(6 \%)$ defaulted after the initial visit and $78(80 \%)$ attended for 6 months or more.

Of the 739 overweight patients who attended for follow-up 6r (8\%) gained weight but $242(33 \%)$ lost more than $50 \%$ of their excess weight. This apparent 
success is less marked when weight change is considered in terms of $1 b$ lost, with 172 patients $(23 \%)$ achieving a weight loss of $20 \mathrm{lb}$ or more. The proportion of excess weight lost was greater with lesser degrees of overweight and also in those patients who attended for 6 months or more or were over 40 years of age. It was not influenced to any appreciable extent by sex, occupation or the presence of complicating disease.

The intake of soil by the grazing sheep. By A. C. FIELD, Animal Diseases Research Association, Moredun Institute, Gilmerton, Edinburgh, and D. PuRves, Edinburgh School of Agriculture

Ingested soil is a source of minerals to a grazing ruminant. Its importance depends upon the amount of soil ingested, the ratio of the concentration of mineral in soil to that in herbage and the ability of the ruminant to use the mineral in the form in which it exists in soil. On the other hand, constituents of soil, such as clay, may interfere with the absorption of some minerals from the alimentary tract.

Faeces from four adult wethers weighing about $80 \mathrm{~kg}$ grazing a perennial ryegrasswhite clover pasture, were collected individually for nine periods of 6 days each during May to December I962. The amount of soil ingested was calculated from the ratio of the concentration of titanium in faeces to that in soil collected from the surface of the field grazed by the sheep and by assuming the soil to be indigestible. The assumption was also made that the titanium content of the herbage ingested was negligible in relation to the content of the contaminating soil. The dry-matter intake was calculated from the concentration of nitrogen in faeces and the relationship between digestibility and faecal nitrogen found by Holmes \& Osman (I962).

The estimated intakes of soil, both in absolute terms and as a percentage of drymatter intake are given in Table I. From May to August when herbage was abundant the intake was low. From September to December, a period of scarcity of herbage, the intake of soil increased dramatically. Evidently, during the winter months ingested soil constitutes a substantial fraction of the sheep's dry-matter intake.

Table 1. Intake of soil, expressed in g/day (1) and as percentage of daily dry-matter intake (2), by four adult wethers, at pasture from May until December 1962

$\begin{array}{lcllcc} & \text { I } & 2 & & \text { I } & 2 \\ \text { Early May } & \mathbf{2 2} & \mathrm{I} \cdot 4 & \text { Early September } & 54 & 4 \cdot 2 \\ \text { Late May } & 9 \cdot 2 & 0.42 & \text { Early October } & 17 \text { I } & \text { I I } \\ \text { Late June } & 2 \mathrm{I} & \mathrm{I} \cdot 2 & \text { Early November } & 1 \text { I I } & 6 \cdot 8 \\ \text { Mid July } & 16 & 0.90 & \text { Mid December } & 198 & 14 \\ \text { Early August } & 24 & \mathrm{I} \cdot 7 & & & \end{array}$

For the nutritionally important mineral elements with high concentrations in soil relative to herbage, e.g. cobalt, soil is an important source throughout the year and it may be the main source in winter. On the other hand, for those mineral elements with a relatively low soil to herbage ratio, e.g. magnesium, soil could only be an important source during periods of high soil intake and low herbage availability. 
The degree of utilization of nutritionally important mineral elements in the soil by the animal, however, still remains to be ascertained.

\section{REFERENCE}

Holmes, W. A. \& Osman, H. el S. (1960). Anim. Prod. 2, I3 I.

The endogenous loss of magnesium in the adult rat and the effect of digestibility of diet on the transit time through the alimentary tract. By B. S. W. Smith (introduced by A. C. Field), Animal Diseases Research Association, Moredun Institute, Gilmerton, Edinburgh

In adult rats given a magnesium-free diet Smith \& Field (1963) showed that the endogenous loss decreased during the ist week and then remained constant up to I 8 days. However, it was not known when $\mathrm{Mg}$ from the previous diet would be completely excreted or whether the endogenous loss would be reduced during longer periods of deficiency.

In separate trials an adult female rat was given ad lib. the stock rat nuts, and synthetic fibre-free control and Mg-free diets (Smith \& Field, I963). The times taken for complete excretion of a single dose of ${ }^{51} \mathrm{Cr}$ were $3^{\circ}, 85$ and 80 h respectively.

To determine the endogenous loss of $\mathrm{Mg}$ each of seven adult female rats (average weight $335 \mathrm{~g}$ ) was fed the synthetic control diet for 7 days and the $\mathrm{Mg}$-free diet for a further 45 days. The diet was mixed with water containing water-soluble vitamins (Smith \& Field, I963) in the proportion $40 \mathrm{~g}$ diet to $16 \mathrm{ml}$ liquid, and $6 \mathrm{ml}$ of the slurry ( $\equiv 5 \mathrm{~g}$ dry diet) was fed once daily by stomach tube. This diet was supplemented by giving the drinking fluid containing sucrose $(100 \%, \mathrm{w} / \mathrm{v})$ ad lib. and enabled the rats to maintain weight when fed the control diet. A single dose of ${ }^{51} \mathrm{Cr}$ was given with the last dose of control diet. The radioactivity of the individual faeces samples obtained during the rst week was determined. After 7 days all the rats had excreted at least $95 \%$ of the total radioactivity. The mean daily endogenous $\mathrm{Mg}$ excretion for each rat for successive weeks is shown in Table $\mathbf{r}$.

Table I. Mean daily endogenous loss of magnesium for adult female rats on a Mg-free diet

$\begin{array}{cccccccc}\text { Rat no. } & \text { I } & 2 & 3 & 4 & 5 & 6 & 8 \\ \text { Ist week } & 0.552 & 0.698 & 0.509 & 0.576 & 0.632 & 0.564 & 0.594 \\ \text { 2nd week } & 0.453 & 0.348 & 0.332 & 0.427 & 0.378 & 0.530 & 0.375 \\ \text { 3rd week } & - & 0.378 & 0.317 & 0.452 & 0.388 & - & 0.317 \\ 4^{\text {th week }} & - & 0.336 & 0.298 & - & 0.425 & - & 0.237 \\ \text { 5th week } & - & 0.407 & 0.336 & - & 0.351 & - & 0.237 \\ \text { 6th week } & - & 0.242 & 0.288 & - & 0.184 & - & 0.265 \\ \text { 7th week } & - & 0.208 & - & - & 0.336 & - & 0.354\end{array}$

The results obtained with ${ }^{51} \mathrm{Cr}$ show that the time taken for food to pass through the gut is very much increased as the amount of indigestible material in the diet is reduced. The endogenous loss of $\mathrm{Mg}$ fluctuates on this diet but is not markedly reduced as deficiency progresses. 


\section{The use of in vitro digestibilities of dried grasses for the prediction of their} energy values for ruminants. By D. G. Armstrong, Department of Agricultural Biochemistry, University of Newcastle upon Tyne, and R. H. AlEXANDER and Mary McGowan, Department of Chemistry, West of Scotland Agricultural College, Ayr

The values of twelve dried grasses as sources of energy for sheep have recently been determined (Armstrong, 1964a). The accuracy of prediction of these values from a knowledge of either dry-matter digestibility determined in vivo or chemical composition of the dry matter, has been reported (Armstrong, r964 $b$ ). This lastmentioned study, relating specifically to the twelve grasses referred to above, and that of Armstrong, Blaxter \& Waite (I964), which included data on an additional four herbages, have shown that accuracies of prediction of metabolizable and net energies for maintenance or for production based on in vivo digestibility of either dry matter or of gross energy compared favourably with accuracies of prediction for these energy categories based on chemical composition of the dry matter.

The digestibilities of organic matter for each of the twelve grasses has been determined by the in vitro method (Alexander \& McGowan, 196I) modified by the addition of $0.02 \mathrm{M}$-ammonium sulphate to the rumen liquor-buffer mixture. The difference between dried and ignited residue weights after allowance for control-tube residues is taken as indigestible organic matter. Using this technique the filter aid need not be measured accurately. The correlation coefficient and derived regression equation relating $\%$ digestibility of organic matter determined in vivo with sheep fed at the maintenance level $\left(D_{1}\right)$ to that determined in vitro $(X)$ were 0.986 (significant $P<0.00 \mathrm{I})$ and $D_{1}=0.92 X+\mathrm{I} 2.48$. The comparable data for in vivo digestibility determined when sheep were fed twice the maintenance level $\left(D_{2}\right)$ and in vitro digestibility were 0.989 (significant $P<0.00 \mathrm{I}$ ) and $D_{2}=\mathrm{I} \cdot \mathrm{I}_{5} X-6 \cdot 12$.

Regression equations of metabolizable and of net energies for maintenance and production on digestibility of organic matter determined in vitro are given below.

$$
\begin{array}{ccc}
\text { Regression } & \begin{array}{c}
\text { Residual } \\
\text { Residual } \\
\text { standard deviation } \\
\text { as \% of mean }
\end{array} \\
\mathrm{ME}=0.037 D+0.122 * * * & \pm 0.083 & \pm 3.0 \\
\mathrm{NEM}=0.035 D-0.462 * * * & \pm 0.076 & \pm 3.8 \\
\mathrm{NEF}=0.034 D-1.078 * * & \pm 0.117 & \pm 8.3 \\
\text { ***All regressions significant at } P<0.001 .
\end{array}
$$

where $D=\%$ digestibility of organic matter determined in vitro, $\mathrm{ME}=\mathrm{kcal}$ metabolizable energy $/ \mathrm{g} \mathrm{dry}$ matter, $\mathrm{NEM}=\mathrm{kcal}$ net energy (maintenance)/g dry matter and $\mathrm{NEF}=\mathrm{kcal}$ net energy (fattening)/g dry matter. 
These studies show that the in vitro determination of digestibility is of considerable use in predicting the value of dried grasses as sources of energy for ruminants. Accuracies of prediction compare favourably with those based on chemical composition (see Armstrong, I $964 b$ ). Furthermore, the determination of digestibility has the additional advantage of providing a measure of the faccal energy loss which is not only the major determinant of the energy value/unit of food but also of very considerable importance as a factor controlling voluntary feed intake by ruminants (Armstrong, I964a)

\section{REFERENCES}

Alexander, R. H. \& McGowan, M. (x961). F. Brit. Grassl. Soc. 16, 275.

Armstrong, D. G. (1964a). F. agric. Sci. (In the Press.)

Armstrong, D. G. (1964b). Agric. Progr. (In the Press.)

Armstrong, D. G., Blaxter, K. L. \& Waite, R. (1964). F. agric. Sci. (In the Press.)

Fluorine retention in growing lambs: a comparison of balance data with bone analysis. By R. G. Hemingway and Moira J. Young, Department of Animal Husbandry and Veterinary Preventive Medicine, University of Glasgow

Eight-week old lambs were fed a low-phosphorus diet of concentrates and straw (Hemingway, I963) supplemented with either dicalcium phosphate or a natural rock phosphate. The basal diet contained Io $\mu \mathrm{g} / \mathrm{g}$ fluorine. After about 14 weeks on this diet, ten lambs receiving each of these $\mathrm{P}$ sources were kept in turn in metabolism crates to determine individual $F$ (and $P$ ) intakes, losses and retentions. Eightday collection periods were used. The lambs were slaughtered within I-4 weeks after the completion of the balance experiments, when they were 26 weeks old. F was determined in food, urine, faeces and rib-bone ash by titration with thorium nitrate in the presence of alizarin (Analytical Methods Committee, 1958).

Table I details the amounts of $F$ in the rib-bone ash, the daily intakes and urine losses and the amounts of $\mathrm{F}$ retained (calculated by difference after allowing for faecal losses). The concentration of $\mathrm{F}(\mu \mathrm{g} / \mathrm{g})$ in the diets approximated numerically to the daily intakes (mg), as the lambs consumed about I $\mathrm{kg}$ of food each day.

$\mathrm{F}$ retention was highly correlated with $\mathrm{F}$ intake $(r=0.966 ; P<0.00 \mathrm{I})$. The concentration of $\mathrm{F}$ in rib-bone ash was highly correlated with both $\mathrm{F}$ intake $(r=$ $0.870 ; P<0.0 \mathrm{I})$ and with $\mathrm{F}$ retention $(r=0.884 ; P<0.00 \mathrm{I})$. Urine $\mathrm{F}$ output $(\mathrm{mg} / \mathrm{day})$ was correlated, but to a much less marked degree, with both $\mathrm{F}$ intake $(r=0.587$; $P<0.0 \mathrm{I})$ and $\mathrm{F}$ retention $(r=0.437 ; P<0.05)$. Urine $\mathrm{F}(\mathrm{mg} /$ day $)$ also was correlated with the concentration in the rib-bone ash $(r=0.466 ; P<0.05)$.

Urine $\mathrm{F}$ concentrations $(\mu \mathrm{g} / \mathrm{ml}$ ) (which are not presented here), as opposed to daily urine outputs $(\mathrm{mg})$, were even less useful as diagnostic measures of $\mathrm{F}$ intake and retention, and were valueless for animals at this stage of growth.

The mean retentions of $\mathrm{F}$ were $36 \cdot 7 \%$ and $38 \cdot 6 \%$ of intake for the dicalcium phosphate and mineral phosphate groups. There were no dental or skeletal abnormalities resulting from the increased fluorine intakes. 
Table $x$. Daily $F$ intakes and urine losses, daily $F$ retentions and $F$ concentrations in rib-bone ash of twenty growing lambs

$\begin{array}{rccc}\text { Intake } & \begin{array}{c}\text { Dicalcium phosphate } \\ \text { Urine }\end{array} & \text { Retained } \\ & \begin{array}{c}\text { Rib-bone } \\ \text { ash F } \\ (\mu \mathrm{g} / \mathrm{g})\end{array} \\ 9.6 & 4.6 & 3.0 & \text { I089 } \\ 10.4 & 9.4 & 1.5 & 1045 \\ 10.4 & 5.6 & 2.5 & \text { I305 } \\ 18.0 & 5.0 & 8.9 & \text { I555 } \\ 24.0 & 12.9 & 5.5 & \text { I333 } \\ 24.0 & 12.6 & 8.1 & \text { II } 45 \\ 24.0 & 10.0 & 10.6 & \text { I555 } \\ 29.0 & 12.0 & 10.1 & \text { I6I6 } \\ 29.0 & 9.3 & 11.9 & \text { I975 } \\ 29.0 & 6.0 & 13.5 & \text { I965 }\end{array}$

\begin{tabular}{|c|c|c|c|}
\hline \multicolumn{4}{|c|}{ Mineral phosphate } \\
\hline Intake & Urine & Retained & \multirow{2}{*}{$\begin{array}{c}\text { Rib-bone } \\
\text { ash } \mathrm{F} \\
(\mu \mathrm{g} / \mathrm{g})\end{array}$} \\
\hline \multicolumn{3}{|c|}{ (mg F/day) } & \\
\hline $29 \cdot 0$ & 14.0 & $9 \cdot 0$ & 2329 \\
\hline $33^{\prime} \mathrm{I}$ & $11 \cdot 9$ & 14.0 & 2355 \\
\hline $33^{\prime} \mathrm{I}$ & $4^{\prime} I$ & 19.4 & 2355 \\
\hline $5^{8 \cdot 4}$ & $9 \cdot 3$ & $24 \cdot 9$ & $265 \mathrm{I}$ \\
\hline $67 \cdot 0$ & I I 4 & $24 \cdot 6$ & 2613 \\
\hline 67.0 & $10 \cdot 8$ & $28 \cdot 6$ & 1815 \\
\hline $67 \cdot 0$ & $I I \cdot I$ & $32 \cdot 4$ & $333^{\circ}$ \\
\hline $\mathrm{I} 43^{.8}$ & I I 6 & $60 \cdot 0$ & 3190 \\
\hline I $50 \cdot 6$ & 13.0 & $50 \cdot 0$ & 3673 \\
\hline$\times 55^{\circ} \mathrm{O}$ & $16 \cdot I$ & $48 \cdot 0$ & $389 \mathrm{I}$ \\
\hline
\end{tabular}

\section{REFERENCES}

Analytical Methods Committee (1958). Analyst, 83, 230.

Hemingway, R. G. ( $\left.\mathrm{Ig}_{3}\right)$. Proc. Nutr. Soc. 22, xvi.

Agent and target in amino acid interactions. By G. H. Smrth and D. Lewrs, University of Nottingham School of Agriculture

In addition to specific amino acid inadequacies the absence of an ideal dietary amino acid balance will also result in a retardation of growth. Though it may be possible to classify amino acid interactions into imbalances, antagonisms or toxicities (Elvehjem, 1956) it is not justifiable to infer that,disparate mechanisms are involved. Further information on the nature of any interaction may be obtained by studying the circumstances under which each amino acid can behave as the agent of interaction effects or as the target which must be supplied to counteract these effects.

It has been observed that chicks fed a diet low in arginine grow less rapidly when excess lysine is added and that the addition of supplementary arginine restores growth (Lewis, Smith \& Payne, I 963). The interaction between lysine and arginine has been examined in more detail. The addition of excess histidine to a diet of maize and maize gluten meal marginally inadequate in arginine did not retard growth (Table I). A similar diet (basal 2) was used to determine whether an amino acid other than arginine could become the target when lysine was the agent. Both the arginine and tryptophan levels were low and a growth depression was produced by adding lysine. It was alleviated only by arginine supplementation: tryptophan addition in the presence of lysine further depressed growth. In basal diet 3 the tryptophan level was further reduced by using some zein and the arginine was supplemented to an adequate level. Although growth was improved by adding tryptophan the addition of lysine produced no growth depression.

It is proposed that there exists a specific interaction between lysine and arginine: it is possible that many of the ill-defined effects of amino acid imbalance may reflect an interaction between specific pairs of amino acids. 
Table I. Growth of chicks from 7 to $2 \mathrm{I}$ days in response to amino acid supplementation

\begin{tabular}{lcccc} 
& & \multicolumn{3}{c}{ Live-weight gain (as \% of that on basal diet) } \\
\cline { 3 - 5 } Amino acid & Level added & $\begin{array}{c}\text { Basal diet I } \\
(65,90,150,150)^{*}\end{array}$ & $\begin{array}{c}\text { Basal diet } 2 \\
(65,90,150,60)^{*}\end{array}$ & $\begin{array}{c}\text { Basal diet } 3 \\
(85,110,110,30)^{*}\end{array}$ \\
Arg & 20 & 110 & 100 & 100 \\
Lys & 60 & 80 & 65 & 100 \\
His & 100 & 100 & - & 140 \\
Try & 100 & - & 105 & 100 \\
Arg + Lys & $20+60$ & - & 90 & 130 \\
Arg + Try & $20+100$ & - & 100 & 142 \\
Try+Lys & $100+60$ & - & 70 & 130 \\
Arg + Lys +Try & $20+60+100$ & & & 70
\end{tabular}

*Levels of Arg, Lys, His and Try respectively as \% of level recommended by (USA) National Research Council (1960).

\section{REFERENCES}

Elvehjem, C. A. (1956). Fed. Proc. 15, 965 .

Lewis, D., Smith, G. H. \& Payne, C. G. (1963). Brit. F. Nutr. 17, 415.

National Research Council (1960). Publ. nat. Res. Coun., Wash., no. 827.

Chick bioassay of lysine. By H. O. Uwaegbute and D. Lewis, University of Nottingham School of Agriculture

In any assessment of amino acid availability that involves the measurement of the rate of growth of chicks in relation to graded inclusions of standard amino acid and test protein, all responses to the test protein other than those due to its contribution of the amino acid being assayed must be eliminated. In this respect it is essential to avoid the differentials in dietary protein levels that generally result from the addition of graded levels of test protein. Furthermore, conditions of relative amino acid imbalance in basal diets and the varied changes imposed upon these by adding test protein will only serve to distort the response of the chick to the amino acid being assayed. Failure to eliminate these so-called protein effects considerably reduces the value of assay procedures so far reported.

In this light an experimental programme has been carried out to establish for the chick an optimum balance of amino acids in the dietary protein (Uwaegbute \& Lewis, I 963) and to create a situation in which amino acid and test-protein supplementation can be effected without invoking the so-called protein effect.

In the bioassay procedure that has been adopted records were kept of the rate of live-weight gain, of proportional nitrogen retention and of the efficiency of food utilization. A series of diets was examined based upon a maize-sesame meal-dried whey mixture supplemented with lysine. When this was formulated to give a ration of $20 \%$ protein satisfactory rates of live-weight gain were recorded (approximately $24 \mathrm{~g} /$ day at $14^{-21}$ days of age). It was demonstrated that if the protein level of the basal diet was dropped from 20 to $16 \%$ the difference could be met by adding a mixture of glutamic acid and essential amino acids that simulated the composition of the basal protein. The assay basal diet was therefore formulated at a protein level 
of $\mathrm{r} 6 \%$ with the addition of the equivalent of $4 \%$ protein in the form of an amino acid mixture. In this way graded levels of the test protein could be included in such a way that in each diet the final protein level was equivalent to $20 \%$. Slight adjustments were made to the amino acid supplement in the knowledge of the amino acid composition of the test protein. All the diets that were fed therefore only varied significantly in their content of the amino acid being assayed, lysine.

Using this bioassay procedure and an analysis of the results by a parallel line technique (Finney, 1952) determinations of available lysine have been made on several samples of fish meals, soya-bean meals and meat meals supplied by the Agricultural Research Council Protein Quality Group. Three samples of fish meals, for example, were selected on the basis of appropriate, moderate and very inadequate heat treatment: the observed values of available lysine in these samples corresponded to 89,75 and $68 \%$ respectively of the total lysine.

\section{REFERENCES}

Finney, D. J. (1952). Statistical Method in Biological Assay. London: Charles Griffin.

Uwaegbute, H. O. \& Lewis, D. (1963). Int. Congr. Nutr. VI. Edinburgh, Programme, page 122.

Glyceride structure and fat digestibility. By R. H. DAvis and D. Lewis, University of Nottingham School of Agriculture

It has been shown that the position of a fatty acid within the glyceride molecule may influence the extent to which it is absorbed. This factor is not of particular importance in the case of unsaturated acids and the shorter-chain saturated acids since they are well absorbed regardless of the form in which they are ingested. In the case of palmitic acid it has been demonstrated by Renner \& Hill (I96I) that the chick utilizes this acid to a considerably greater extent where it is esterified in the $\beta$-position of the glyceride molecule and it is likely that the same is true for stearic and other longer-chained saturated acids. Since palmitic and stearic acids constitute a major portion of fats available for feeding farm animals it is of especial interest to establish conditions for their best utilization.

An investigation has been carried out to evaluate as energy sources in growing pig rations, fats differing in glyceride structure. Assessments were made of digestibility and in a feeding trial of rate of live-weight gain, efficiency of food utilization and carcass composition. The fats used were natural lard in which the palmitic acid is predominantly $\beta$-esterified, interesterified lard with completely random distribution of fatty acids and beef tallow which has saturated acids predominantly $\alpha$-esterified. These fats were incorporated at a level of $10 \%$ in a series of rations for bacon pigs and compared with a basal ration containing no added fat. In the growth trial the pigs received these rations from 50-200 lb live weight. 'The scales of food intake adopted ensured the same supply in terms of protein and of digestible energy for all pigs.

It was demonstrated that glyceride structure influenced the digestibility of the fat. The bulk of the undigested food fat was voided as free acids with only a slight 
increase being observed in the triglyceride content of the faeces. Lard was better digested than interesterified lard and both were better digested than tallow: the actual values recorded were 83,80 and $71 \%$ respectively. No significant differences were obtained in the growth trial.

The largest differences in digestibility that was recorded ( $12 \%$ ) is only equivalent to a difference of approximately $2 \%$ in the digestible energy value of the whole ration. In view of the number of pigs used in the feeding trial (twenty-four) and their variability it is not unexpected that no significant differences were observed. The results confirm that under appropriate circumstances digestibility trials constitute a more sensitive index of nutritive value than feeding trials.

\section{REFERENCE}

Renner, R. \& Hill, F. W. (1961). F. Nutr. 74, 254.

\section{Nitrogen retention by cattle given all-concentrate diets containing different} concentrations of fish meal. By H. B. Bowers, T. R. Preston, I. McDonald, N. A. Macleod and Euphemia B. Philip, Rowett Research Institute, Bucksburn, Aberdeen

In each of two trials, the first at a mean live weight of $I_{5} 0 \mathrm{~kg}$ and the second at $240 \mathrm{~kg}$, eight Friesian steers were given four diets according to a double $4 \times 4$ latin square design. The previous treatment of the animals and their management between trials was according to the general procedure described by Preston, Aitken, Whitelaw, Macdearmid, Philip \& MacLeod (1963). The ingredients were whole barley grain, vitamins $A$ and $D$, cobalt and varying amounts of Peruvian fish meal and bone flour to give concentrations of crude protein in dry matter of approximately $16, \mathrm{r} 8$, 20 and $22 \%$. The diets were made into pellets of $\frac{3}{8}$ in. diam. Feeding was ad lib. from 'self-feed' hoppers and the experimental periods were of $\mathrm{I} 3$ days' duration, nitrogen balance being measured over the last 6 days of each period.

In the first trial $\mathrm{N}$ retention increased from $25 \mathrm{~g}$ to $4 \mathrm{r} \mathrm{g} /$ day $(P<0.00 \mathrm{I})$ and apparent digestibility of dietary $\mathrm{N}$ increased from 70 to $79 \%(P<0.00 \mathrm{I})$ as the crude protein content of the diet increased from 16 to $22 \%$. The retention of dietary $\mathrm{N}$ was approximately $33 \%$ and did not differ significantly between diets of different protein contents. In the second trial $\mathrm{N}$ retention increased from 25 to $37 \mathrm{~g} /$ day as the crude protein content of the diet increased from 16 to $20 \%$, but there was no further increase in retention when the crude protein content was increased to $22 \%$. The corresponding increase in apparent digestibility of dietary $\mathrm{N}$ was from 73 to $78 \%$. The most marked difference in the results of this trial compared with the first was in the utilization of dietary $\mathrm{N}$ which averaged only $20 \%$ compared with $33 \%$ which was obtained with the younger and lighter animals in the first trial. Metabolic faecal $\mathrm{N}$ (g/W $\mathrm{W}^{0.74}$ day) did not change with increasing crude protein content of the diet and was approximately the same at both live weights. Metabolic urinary $\mathrm{N}$ (g/ $\mathrm{W}^{\mathbf{0 . 7 4}}$ day) increased significantly $(P<0.001)$ as the crude protein in the diet increased and it $23(2) 8$ 
was also much higher in the older animals. Thus the reduction in the efficiency of utilization of dietary $\mathrm{N}$ from 33 to $20 \%$, as live weight increased from 150 to $240 \mathrm{~kg}$, is accounted for by an increase in urinary N. It would appear that with rapidly growing cattle there is an increase in endogenous urinary $\mathrm{N}$ with increasing level of performance i.e. live-weight gain, and with increasing stage of maturity.

\section{REFERENCE}

Preston, T. R., Aitken, J. N., Whitelaw, F. G., Macdearmid, A., Philip, E. B. \& MacLeod, N. A. (1963). Anim. Prod. 5, 245.

The One Hundred and Sixty-fifth Meeting of The Nutrition Society was held at Queen Elizabeth College, London, W 8 on Friday, 22 May 1964, at 10.15 am, when the following papers were read:

\section{Further studies on copper sulphate and molasses distillers dried solubles} as growth stimulants in the diet of growing pigs. By R. S. BARBER, R. Braude and K. G. Mitchell, National Institute for Research in Dairying, Shinfield, Reading

In previous work (Barber, Braude \& Mitchell, I 962), the addition of $2 \frac{1}{2} \%$ molasses distillers dried solubles (E. C. Feed; National Chemical Products Ltd) to a diet containing animal protein significantly improved growth rate in growing pigs by $5 . \mathrm{I} \%$, whereas addition of copper sulphate (supplying 250 p.p.m. Cu) increased growth rate by $14.5 \%$. Although both additives similarly increased rate of food consumption, only copper improved the efficiency of food utilization.

The present experiment was carried out to obtain further information on E. C. Feed and to investigate whether there was any supplementary effect on performance when both copper and E. C. Feed were added to the diet as indicated in a preliminary report by Robinson, Coey, Holme \& Kormos (1959-60). Forty-eight individually fed Large White pigs, in twelve lots of four litter-mates each and on experiment from 9 weeks of age to bacon weight, were used to compare the effect on performance and carcass quality of the addition to the diet either of copper sulphate $(250$ p.p.m. $\mathrm{Cu}$ ), or $2 \frac{1}{2} \%$ E. C. Feed or of both additives together. The basal diet fed and the method of feeding were similar to that used previously (Barber et al. 1962) except that a lower level of white-fish meal was included $(7 \%$ reduced to $3 \%$ from $\mathrm{I} 20 \mathrm{lb}$ live weight), and the pigs were restricted to a daily maximum of $6 \mathrm{lb}$ meal instead of $6 \frac{1}{2} \mathrm{lb}$.

Copper sulphate significantly improved growth rate (by $8 \cdot 0 \%$ ) and efficiency of food utilization (by $4 \cdot 6 \%$ ) whereas E. C. Feed had no significant effect on either. Pigs given both copper and E. C. Feed performed similarly to those given copper alone. There were no significant differences between any of the treatments in rate of food consumption; dressing percentage; carcass length; shoulder depth; shoulder 